\title{
Fluorescence in situ hybridization analysis of the $A L K$ gene in 2,045 non-small cell lung cancer patients from North-Western Spain (Galicia)
}

\author{
MARÍA SÁNCHEZ-ARES ${ }^{1}$, JOSÉ M. CAMESELLE-TEIJEIRO ${ }^{1,2}$, SERGIO VÁZQUEZ-ESTÉVEZ ${ }^{3}$, \\ MARTÍN LÁZARO-QUINTELA ${ }^{4}$, ÁNGEL VÁZQUEZ-BOQUETE ${ }^{1}$, FRANCISCO J. AFONSO-AFONSO ${ }^{5}$, \\ JOAQUÍN CASAL-RUBIO ${ }^{4}$, ANA L. GONZÁLEZ-PIÑEIRO ${ }^{6}$, YOLANDA RICO-RODRÍGUEZ ${ }^{1}$, \\ JOSÉ L. FÍRVIDA-PÉREZ ${ }^{7}$, JUAN RUÍZ-BAÑOBRE ${ }^{8}$, ELENA COUSO ${ }^{1}$, LUCÍA SANTOMÉ ${ }^{9}$, \\ RAQUEL PÉREZ-BECERRA ${ }^{1}$, ROSARIO GARCÍA-CAMPELO ${ }^{10}$, MARGARITA AMENEDO $^{11}$, \\ CRISTINA AZPITARTE-RAPOSEIRAS ${ }^{12}$, JOSÉ ANTÚNEZ ${ }^{1,2}$ and IHAB ABDULKADER ${ }^{1}$
}

${ }^{1}$ Department of Anatomic Pathology, Clinical University Hospital, Galician Healthcare Service (SERGAS),

15706 Santiago de Compostela; ${ }^{2}$ Department of Anatomic Pathology, University of Santiago de Compostela,

15782 Santiago de Compostela; ${ }^{3}$ Department of Medical Oncology, Lucus Augusti University Hospital, SERGAS,

27003 Lugo; ${ }^{4}$ Department of Medical Oncology, University Hospital Complex, SERGAS, 36312 Vigo;

${ }^{5}$ Department of Medical Oncology, University Hospital Complex Arquitecto Marcide-Novoa Santos, SERGAS, 15405 Ferrol;

${ }^{6}$ Department of Anatomic Pathology, University Hospital Complex, SERGAS, 36312 Vigo; ${ }^{7}$ Department of Medical Oncology,

Clinical University Hospital, SERGAS, 32005 Ourense; ${ }^{8}$ Department of Medical Oncology, Clinical University Hospital,

SERGAS, 15706 Santiago de Compostela; ${ }^{9}$ Department of Medical Oncology, Povisa Hospital, 36211 Vigo;

${ }^{10}$ Department of Medical Oncology, Clinical University Hospital, SERGAS, 15006 A Coruña;

${ }^{11}$ Department of Medical Oncology, Centro Oncológico de Galicia, 15009 A Coruña;

${ }^{12}$ Department of Medical Oncology, Clinical University Hospital, SERGAS, 36164 Pontevedra, Spain

Received February 19, 2016; Accepted May 10, 2016

DOI: $10.3892 / \mathrm{ol} .2016 .4788$

\begin{abstract}
Identification of anaplastic lymphoma receptor tyrosine kinase $(A L K)$ gene rearrangements is a standard diagnostic test in patients with advanced non-small cell lung cancer (NSCLC). The current study describes the experience of $A L K$ rearrangement detection of a referral center in the public health care system of Galicia in North-Western Spain. The fluorescence in situ hybridization (FISH) patterns of the $A L K$ gene and the clinical and pathological features of these patients are reported. This study is also of interest for comparative purposes due to the relative geographical isolation of the area, which could have contributed to particular genetic features. A total of 2,045 tissue samples from NSCLC patients were collected between October 2010 and July 2015 and tested for $A L K$ rearrangements by FISH. Examination
\end{abstract}

Correspondence to: Dr Ihab Abdulkader, Department of Anatomic Pathology, Clinical University Hospital, Galician Healthcare Service (SERGAS), Travesía da Choupana s/n, 15706 Santiago de Compostela, Spain

E-mail: ihab.abdulkader.nallib@sergas.es

Key words: non-small cell lung cancer, anaplastic lymphoma receptor tyrosine kinase, fluorescence in situ hybridization, biopsy, cytology of 1,686 paraffin-embedded tissue specimens and 395 cytological samples ( 306 cell block preparations and 53 cytological smears) was conducted, and any associations between the FISH results and clinicopathological features were assessed. The rate of successful evaluation was marginally higher in tissue samples than in cytological samples (92.9\% vs. 84.1\%); this difference was not significant. $A L K$ rearrangements were identified in 82 patients(4\%): 65 (79.3\%) in tissue specimens, $15(18.3 \%)$ in cell block samples and $2(2.4 \%)$ in cytological smears. This genetic translocation appeared to be associated with a non-smoking history, younger age, female gender, stage IV and adenocarcinoma histological type. The findings demonstrate that $A L K$ evaluation by FISH is feasible in tissue and cytological samples. The clinical and pathological features of the $A L K$-positive series of patients are similar to those previously reported in the literature.

\section{Introduction}

Recent advances in the biology of non-small cell lung cancer (NSCLC) have identified driver mutations that can predict response to the therapy. This molecularly targeted therapy has dramatically improved results for patients whose tumors harbor somatically activated oncogenes, such as epidermal growth factor receptor $(E G F R)$, anaplastic lymphoma receptor tyrosine kinase $(A L K)$, ret proto-oncogene $(R E T)$ or ROS 
proto-oncogene 1 (ROS1) (1-3). Although EGFR mutations and $A L K, R E T$ and ROS 1 translocations are predominantly detected in lung adenocarcinomas from never-smokers and light smokers, these associations are not absolute; thus, clinical profile must not be used to exclude patients from molecular testing for specific alterations (4).

Activating rearrangements of $A L K$ gene are detectable in 1.9-6.8\% of NSCLC cases (5-9). In these tumors, a fusion gene involving echinoderm microtubule associated protein-like 4 (EML4) and $A L K(E M L 4-A L K)$ encodes a chimeric protein with constitutive tyrosine kinase activity that confers transformation potential and responsiveness to specific targeted inhibitors (5). Whereas the fused $A L K$ gene region remains constant (exon 20), different EML4 exons can be affected, generating several variants; other $A L K$ fusion partners have also been reported $(10,11)$. In patients with $A L K$-positive NSCLC, the use of crizotinib, an oral ATP-competitive selective inhibitor of the $A L K$ tyrosine kinase, along with a new generation of $A L K$ tyrosine kinase inhibitors (alectinib and ceritinib), has demonstrated superiority over standard chemotherapy $(3,4)$.

Fluorescence in situ hybridization (FISH), bright-field dual-color chromogenic in situ hybridization (12), immunohistochemistry (IHC) $(7,12)$ and reverse transcriptase-polymerase chain reaction (13) are available methods for the detection of $A L K$ rearrangements. ALK FISH has been recognized as the most sensitive method (9). Recently, the FDA has approved the Ventana ALK (D5F3) CDx Assay (Roche, Tucson, AZ, USA) to identify patients for crizotinib therapy. Ultrasensitive IHC assays may obviate FISH confirmation in positive IHC cases; however, the likelihood of false negative IHC results demands FISH testing, at least in some situations $(7,8,12)$. Currently, the only approved FISH assay for the detection of $A L K$ positivity, as a companion diagnostic tool for crizotinib-based treatment eligibility, is the Vysis ALK Break Apart FISH Probe Kit (Abbott Molecular, Des Plaines, IL, USA).

In the current study, we describe our experience of FISH $A L K$ rearrangement detection in 2,045 routine diagnostic samples in the public health care system of Galicia (Spain). This report is of particular interest for comparative purposes due to Galicia's isolation in North-Western Spain and its specific cultural characteristics, which may contribute to the emergence of genetic diversity (14).

\section{Materials and methods}

Patients and samples. A total of 2,045 unselected samples of NSCLC from patients in 9 hospitals of the Galician public health care system (Spain), collected between October 2010 and July 2015, were investigated. Samples were received as buffered formalin-fixed, paraffin-embedded tissue biopsies, cell blocks and cytological smears. In the referral center (Clinical University Hospital, Santiago de Compostela, Spain), pathologists verified the adequacy of the samples and reviewed the diagnosis according to the World Health Organization criteria (1). For all patients, medical records were reviewed, and written informed consent obtained. The Independent Ethics Committee of Galicia (Galician Healthcare Service; SERGAS) approved the study protocol, which was conducted in accordance with the Declaration of Helsinki and applicable Spanish laws.
ALK FISH analysis. The ALK genetic status of each patient was evaluated by FISH in representative tumor areas, with an LSI $A L K$ dual-color, break-apart rearrangement probe (Vysis $A L K$ Break Apart FISH Probe Kit, Abbott Molecular Inc.), following the manufacturer's protocol. In each case, 50 non-overlapping nuclei were examined by fluorescence microscope (BX51; Olympus Corporation, Barcelona, Spain). The kit included red (3') and green (5') break-apart probes. ALK was determined to be not rearranged when the two signals were adjacent or fused (appearing yellow under an Orange/Green V2 filter) or when there was a single green signal. $A L K$ was considered positive (rearranged) when $\geq 1$ set of red and green signals were $\geq 2$ signal diameters apart, or when a single red signal was present. A sample was considered negative for $A L K$ if $<5$ cells out of $50(<10 \%)$, and positive when $>25$ cells out of 50 ( $>50 \%)$, exhibited split $A L K 5^{\prime}$ and $3^{\prime}$ probe signals or isolated 3 ' signals. With borderline results, when the number of positive cells was 5-25 (10-50\%), a second reader evaluated the slide: First and second cell count readings were added together and a percentage out of 100 cells was calculated. If the positive cell percentage was $\geq 15 \%$, the sample was considered positive.

Statistical analysis. Statistical analysis was conducted with SPSS version 19.0 (IBM SPSS, Armonk, NY, USA). The association between $A L K$ mutation status and clinicopathological features was calculated using Pearson's $\chi^{2}$ test or Fisher's exact test. $\mathrm{P}<0.05$ was considered to indicated a statistically significant difference.

\section{Results}

ALK assessment. The 2,045 samples of NSCLC included 1,686 (82.4\%) tissue biopsies, 306 (15\%) cell block samples and $53(2.6 \%)$ cytological smears. Among the total samples examined, 1,866 (91.2\%) could be tested by FISH (Fig. 1). Specifically, 1,566 (92.9\%) tissue biopsies, 256 (83.7\%) cell blocks and $46(86.8 \%)$ cytological smears could be assessed. In the remaining $179(8.8 \%)$ samples, the FISH result was not obtained owing to insufficient/non-representative tumor material $(n=143 ; 79.9 \%)$ or to assay failure $(n=36 ; 20.1 \%)$ due to pre-analytical factors (poor fixation, decalcification treatment, etc.). The rate of successful evaluation was not significantly higher in histological samples compared with cytological samples (92.9\% vs. 84.1\%). Additionally, no differences were found between cell blocks and cytological smears $(83.7 \%$ vs. $86.8 \%)$.

ALK rearrangement. $A L K$ rearrangements were identified in 82 (4\%) out of 2,045 tumor samples: 65 (79.3\%) tissue biopsies, $15(18.3 \%)$ cell blocks and $2(2.4 \%)$ cytological smears (Table I). The mean percentage of $A L K$-positive cells was $52 \%$ (range, 15-92\%). A typical translocation pattern was observed in $62(75.6 \%)$ cases, and the remaining cases (24.4\%) exhibited a split pattern (Fig. 1).

Clinicopathological findings. The clinicopathological features of the 2,045 NSCLC patients are summarized in Table I. The majority were male $(69.4 \%)$ and ex-smokers $(38.3 \%)$ or current smokers (37.2\%). At diagnosis, the vast majority were in advanced stage (43.2\% at stage IV). The predominant histological type 
Table I. Clinical and pathological features of patients positive and negative for $A L K$ rearrangement.

\begin{tabular}{|c|c|c|c|c|}
\hline Variable & All cases & $A L K$-negative cases & $A L K$-positive cases & P-value \\
\hline Total, n $(\%$ a) & 2,045 & $1,784(87.2)$ & $82(4.0)$ & \\
\hline Age, years & & & & $<0.001$ \\
\hline Range & $25-94$ & $31-94$ & $25-83$ & \\
\hline Median & 64.0 & 64.4 & 58.0 & \\
\hline Gender, $\mathrm{n}\left(\%^{\mathrm{b}}\right)$ & & & & $<0.001$ \\
\hline Male & $1,420(69.4)$ & $1,262(70.7)$ & $31(37.8)$ & \\
\hline Female & 605 (29.6) & $507(28.4)$ & $49(59.8)$ & \\
\hline Unknown & $20(1.0)$ & $15(0.8)$ & $2(2.4)$ & \\
\hline Histology, n (\%) & & & & 0.017 \\
\hline Adenocarcinoma & $1,559(76.2)$ & $1,352(75.8)$ & $72(87.8)$ & \\
\hline Squamous cell carcinoma & $263(12.9)$ & $239(13.4)$ & $1(1.2)$ & \\
\hline Large cell neuroendocrine carcinoma & $21(1.0)$ & $18(1.0)$ & $2(2.4)$ & \\
\hline Adenosquamous carcinoma & $17(0.8)$ & $16(0.9)$ & $0(0.0)$ & \\
\hline Not otherwise specified & $185(9.0)$ & $159(8.9)$ & $7(8.5)$ & \\
\hline Smoking history, $\mathrm{n}\left(\%^{\mathrm{b}}\right)$ & & & & $<0.001$ \\
\hline Ex-smoker & $783(38.3)$ & $688(38.6)$ & $20(24.4)$ & \\
\hline Smoker & $761(37.2)$ & $661(37.0)$ & $23(28.0)$ & \\
\hline Non-smoker & $372(18.2)$ & $312(17.5)$ & $34(41.5)$ & \\
\hline Unknown & $129(6.3)$ & $123(6.9)$ & $5(6.1)$ & \\
\hline Stage, $\mathrm{n}\left(\%^{\mathrm{b}}\right)$ & & & & $<0.001$ \\
\hline $\mathrm{T} 1$ (T1a+T1b) & $36(1.8)$ & $34(1.9)$ & $1(1.2)$ & \\
\hline $\mathrm{T} 2$ & $39(1.9)$ & $38(2.1)$ & $1(1.2)$ & \\
\hline $\mathrm{T} 3$ & $126(6.2)$ & $117(6.6)$ & $3(3.7)$ & \\
\hline $\mathrm{T} 4$ & $883(43.2)$ & $780(43.7)$ & $47(57.3)$ & \\
\hline Unknown & $961(47.0)$ & $815(45.7)$ & $30(36.6)$ & \\
\hline
\end{tabular}

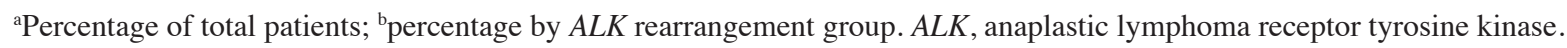

was adenocarcinoma (76.2\%). Significant associations between ALK rearrangement and younger age $(\mathrm{P}<0.001$; Mann-Whitney $\mathrm{U}$ test), female gender $\left(\mathrm{P}<0.001\right.$; Pearson's $\chi^{2}$ test $)$, non-smoking history $(\mathrm{P}<0.001$; likelihood ratio test), stage IV at diagnosis $(\mathrm{P}<0.001$; likelihood ratio test $)$ and the adenocarcinoma histological type $(\mathrm{P}=0.046$; likelihood ratio test) were found. Other $A L K$-positive tumor types were large cell neuroendocrine carcinomas $(n=2)$, squamous carcinoma $(n=1)$ and not otherwise specified carcinomas $(\mathrm{n}=7)$. $A L K$-positive adenocarcinomas $(n=72)$ exhibited a predominantly solid pattern of growth in $45.8 \%$ of cases, with cellular features of signet ring cell carcinoma in $36.4 \%(n=12)$ of these (Table II and Fig. 2). No simultaneous EGFR mutations were detected in any cases.

\section{Discussion}

To the best of our knowledge, this is the largest study on $A L K$ rearrangements in unselected NSCLC patients in a Spanish Caucasian population. It is also the first study in Galicia, North-Western Spain, and is particularly interesting as the adequacy and histology of all samples were reviewed in a single institution by the same pathologists using the same criteria. Although Galicia is relatively isolated, the current results confirm the low frequency of $A L K$ rearrangements (4\%)
Table II. Adenocarcinoma growth patterns of $A L K$ gene rearrangement-positive patients $(n=72)$.

Pattern of growth Cases, $\mathrm{n}$

Solid adenocarcinoma NOS 19

Solid with signet ring cells 12

Acinar adenocarcinoma NOS 13

Cribriform adenocarcinoma 2

Colloid adenocarcinoma 4

Mixed adenocarcinoma ${ }^{a}$ 5

Adenocarcinoma NOS 8

Unknown

${ }^{a}$ Including solid-papillary patterns (1 case), solid-cribriform patterns (1 case), acinar-cribriform patterns (1 case), acinar-solid patterns ( 1 case), and acinar-micropapillary patterns (1 case). NOS, not otherwise specified; $A L K$, anaplastic lymphoma receptor tyrosine kinase.

in unselected Caucasian NSCLC patients, which is marginally higher than values from other areas of Spain (3\%) (6), and within the range of $1.9-6.8 \%$ reported in the literature $(5,7-9)$. 

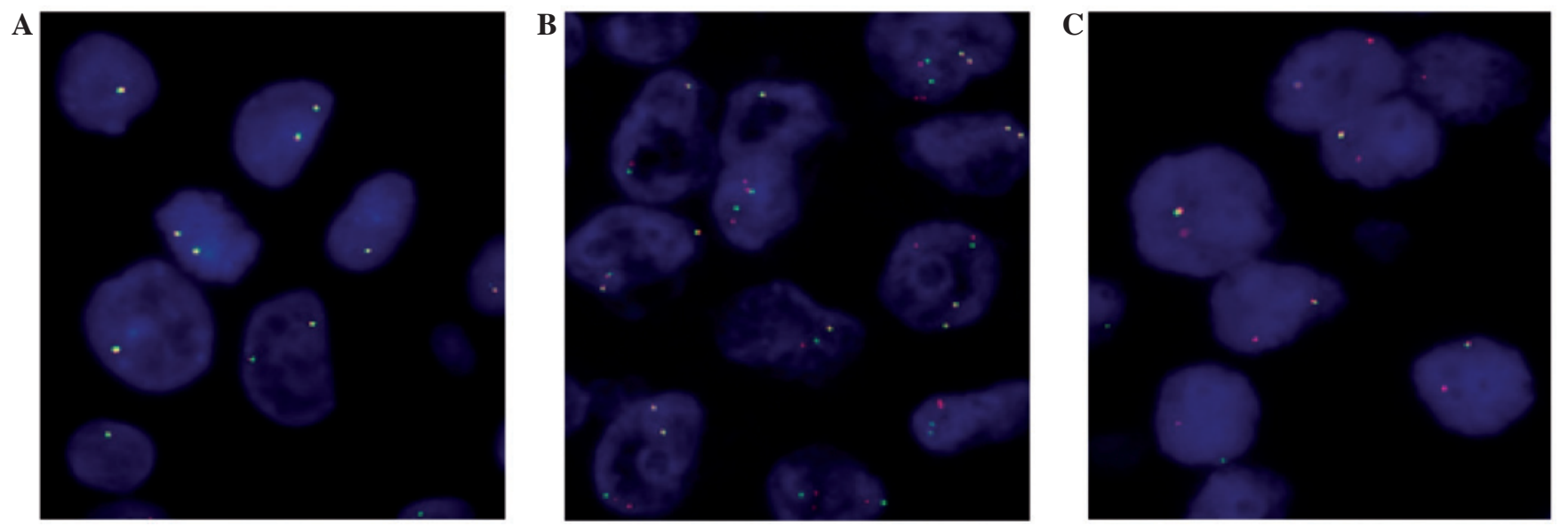

Figure 1. ALK break-apart FISH signals in non-small cell lung cancer. (A) ALK FISH-negative specimen. (B) ALK FISH-positive specimen showing split red and green signals. (C) $A L K$ FISH-positive specimen showing isolated single red signals. $A L K$, anaplastic lymphoma receptor tyrosine kinase; FISH, fluorescence in situ hybridization.
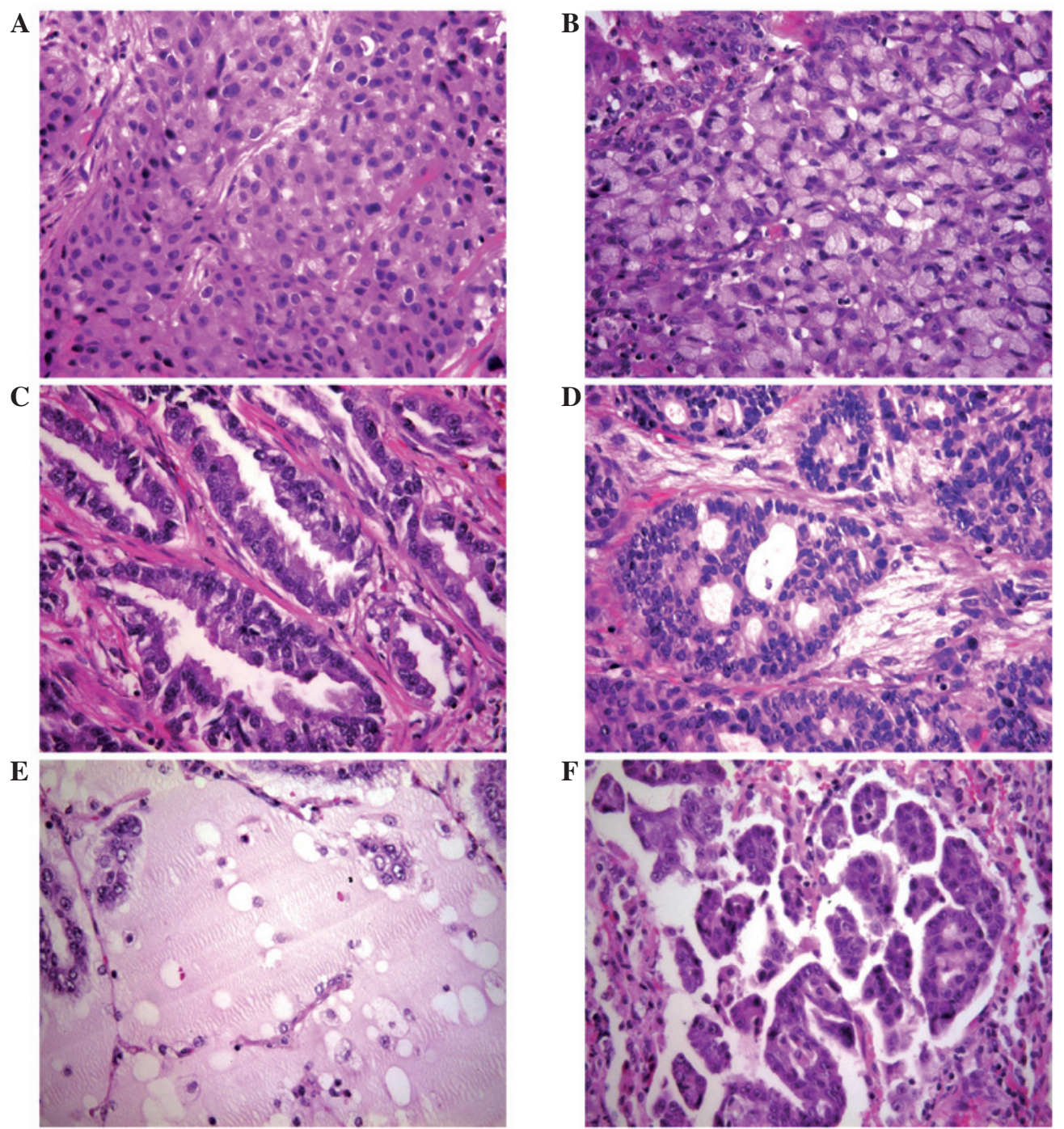

Figure 2. Representative histological patterns of adenocarcinoma tissues. (A) Solid growth pattern, (B) solid pattern with a signet ring cell component, (C) acinar pattern, (D) cribriform pattern, (E) mucinous pattern, and (F) micropapillary pattern. Hematoxylin-eosin staining; original magnification, x400.

The current study utilized the Food and Drug Administration (FDA)-approved $A L K$ break-apart FISH method, with excellent results. The successful evaluation rate difference between tissue samples and cytological samples was not significant $(92.9 \%$ vs. $84.1 \%)$; very similar results were obtained using cell blocks and cytological smears 
(83.7\% vs. $86.8 \%)$. Although technical limitations have been reported in cytological specimens (6), the success rate in the present study was in line with the literature, which reports the feasibility of $A L K$ FISH analysis of cytological samples as ranging from 79-97\% (15). Cytological smears may be preferable for FISH assays as they avoid formalin fixation problems and permit the evaluation of whole nuclei, eliminating overlapping nuclei and nuclear truncation (16). According to FDA guidelines (12), this FISH analysis is applicable on histological samples, however, cytological smears could also be appropriate.

The present study revealed an apparent association of $A L K$ rearrangement with non-smoking, female gender, younger age, stage IV and adenocarcinoma. The significant proportion of $A L K$-positive non-smokers is consistent with previous reports (9), but $55.9 \%$ of the current cases were previous or current smokers, which confirms that smoking is not a reliable criterion on which to predict or exclude $A L K$ rearrangement. $A L K$ positivity was determined to be strongly associated with female gender $(\mathrm{P}<0.001)$; however, controversial results have been reported $(6,8)$. A marginally, non-significantly higher rate of $A L K$ positivity in females has been described in a recent meta-analysis of 6,950 patients (9). The results of the present study and that of Proietti et al (16) found a younger age to be associated with $A L K$ rearrangement. We also found $A L K$ positivity to be associated with stage IV disease; however, analysis of a greater number of patients in other stages would be desirable to reach reliable conclusions. Consistently with previous reports $(6,8,9)$, the current results found $A L K$ rearrangements to be largely, but not completely, restricted to adenocarcinomas, specifically solid or acinar variants or with signet ring cell features. $A L K$ positivity was also identified in one squamous cell carcinoma and two large cell neuroendocrine carcinomas.

In conclusion, the present findings indicated that ALK evaluation by FISH is feasible in tissue and cytological samples. It was also found that ALK translocation is associated with a non-smoking history, a younger age, the female gender, stage IV and the adenocarcinoma histological type. Due to the fact that ALK rearrangement was detected in various histological tumor types, the ALK study should not be restricted to adenocarcinomas.

\section{References}

1. Travis WD, Brambilla E, Burke AP, Marx A and Nicholson AG (eds.): Tumours of the lung. In: Who Classification Of Tumours Of Lung, Pleura, Thymus And Heart. $4^{\text {th }}$ edition. IARC Press, Lyon, France, pp9-151, 2015.

2. Kwak EL, Bang YJ, Camidge DR, Shaw AT, Solomon B, Maki RG, Ou SH, Dezube BJ, Jänne PA, Costa DB, et al: Anaplastic lymphoma kinase inhibition in non-small-cell lung cancer. N Engl J Med 363: 1693-1703, 2010.
3. Patel JN, Ersek JL and Kim ES: Lung cancer biomarkers, targeted therapies and clinical assays. Transl Lung Cancer Res 4: 503-514, 2015.

4. Lindeman NI, Cagle PT, Beasley MB, Chitale DA, Dacic S, Giaccone G, Jenkins RB, Kwiatkowski DJ, Saldivar JS, Squire J, et al: Molecular testing guideline for selection of lung cancer patients for EGFR and ALK tyrosine kinase inhibitors: Guideline from the College of American pathologists, international association for the study of lung cancer, and association for molecular pathology. J Thorac Oncol 8: 823-859, 2013.

5. Soda M,Choi YL,Enomoto M,Takada S, Yamashita Y,Ishikawa S, Fujiwara S, Watanabe H, Kurashina K, Hatanaka H, et al: Identification of the transforming EML4-ALK fusion gene in non-small-cell lung cancer. Nature 448: 561-566, 2007.

6. Vidal J, Clavé S, de Muga S, González I, Pijuan L, Gimeno J, Remón J, Reguart N, Viñolas N, Gironés R, et al: Assessment of ALK status by FISH on 1,000 Spanish non-small cell lung cancer patients. J Thorac Oncol 9: 1816-1820, 2014.

7. Alì G, Proietti A, Pelliccioni S, Niccoli C, Lupi C, Sensi E, Giannini R, Borrelli N, Menghi M, Chella A, et al: ALK rearrangement in a large series of consecutive non-small cell lung cancers: Comparison between a new immunohistochemical approach and fluorescence in situ hybridization for the screening of patients eligible for crizotinib treatment. Arch Pathol Lab Med 138: 1449-1458, 2014.

8. Cabillic F, Gros A, Dugay F, Begueret H, Mesturoux L, Chiforeanu DC, Dufrenot L, Jauffret V, Dachary D, Corre R, et al: Parallel FISH and immunohistochemical studies of ALK status in 3,244 non-small-cell lung cancers reveal major discordances. J Thorac Oncol 9: 295-306, 2014.

9. Zhao F, Xu M, Lei H, Zhou Z, Wang L, Li P, Zhao J and $\mathrm{Hu}$ P: Clinicopathological characteristics of patients with non-small-cell lung cancer who harbor EML4-ALK fusion gene: A meta-analysis. PLoS One 10: e0117333, 2015.

10. Ou SH, Klempner SJ, Greenbowe JR, Azada M, Schrock AB Ali SM, Ross JS, Stephens PJ and Miller VA: Identification of a novel HIP1-ALK fusion variant in non-small-cell lung cancer (NSCLC) and discovery of ALK I1171 (I1171N/S) mutations in two ALK-rearranged NSCLC patients with resistance to Alectinib. J Thorac Oncol 9: 1821-1825, 2014.

11. Iyevleva AG, Raskin GA, Tiurin VI, Sokolenko AP, Mitiushkina NV, Aleksakhina SN, Garifullina AR, Strelkova TN, Merkulov VO, Ivantsov AO, et al: Novel ALK fusion partners in lung cancer. Cancer Lett 362: 116-121, 2015.

12. Conde E, Suárez-Gauthier A, Benito A, Garrido P, García-Campelo R, Biscuola M, Paz-Ares L, Hardisson D, de Castro J, Camacho MC, et al: Accurate identification of ALK positive lung carcinoma patients: Novel FDA-cleared automated fluorescence in situ hybridization scanning system and ultrasensitive immunohistochemistry. PLoS One 9: e107200, 2014.

13. Wang Q, Yang X, He Y, Ma Q, Lin L, Fu P and Xiao H: Droplet digital PCR for absolute quantification of EML4-ALK gene rearrangement in lung adenocarcinoma. J Mol Diagn 17: 515-520, 2015.

14. Mancikova V, Cruz R, Inglada-Pérez L, Fernández-Rozadilla C, Landa I, Cameselle-Teijeiro J, Celeiro C, Pastor S, Velázquez A, Marcos R, et al: Thyroid cancer GWAS identifies 10q26.12 and 6q14.1 as novel susceptibility loci and reveals genetic heterogeneity among populations. Int J Cancer 137: 1870-1878, 2015.

15. Bozzetti C, Nizzoli R, Tiseo M, Squadrilli A, Lagrasta C, Buti S, Gasparro D, Zanoni D, Majori M, De Filippo M, et al: ALK and ROS1 rearrangements tested by fluorescence in situ hybridization in cytological smears from advanced non-small cell lung cancer patients. Diagn Cytopathol 43: 941-946, 2015.

16. Proietti A, Alì G, Pelliccioni S, Lupi C, Sensi E, Boldrini L, Servadio A, Chella A, Ribechini A, Cappuzzo F, et al: Anaplastic lymphoma kinase gene rearrangements in cytological samples of non-small cell lung cancer: Comparison with histological assessment. Cancer Cytopathol 122: 445-1453, 2014. 